\title{
Numerical simulation of the effect of regular and sub-caliber projectiles on military bunkers
}

\author{
Pavel Jiricek ${ }^{\mathrm{a}}$ and Marek Foglar \\ CTU in Prague, Fac. Of Civil Engineering, Thákurova 7, 16629 Praha 6, Czech Republic
}

\begin{abstract}
One of the most demanding topics in blast and impact engineering is the modelling of projectile impact. To introduce this topic, a set of numerical simulations was undertaken. The simulations study the impact of regular and sub-calibre projectile on Czech pre-WW2 military bunkers. The penetrations of the military objects are well documented and can be used for comparison. The numerical model composes of a part from a wall of a military object. The concrete block is subjected to an impact of a regular and sub-calibre projectile. The model is divided into layers to simplify the evaluation of the results. The simulations are processed within ANSYS AUTODYN software. A nonlinear material model of with damage and incorporated strain-rate effect was used. The results of the numerical simulations are evaluated in means of the damage of the concrete block. Progress of the damage is described versus time. The numerical simulation provides good agreement with the documented penetrations.
\end{abstract}

\section{Introduction}

In the end of 1930s, Röchling company used an earlier patent of Škoda Plzeň to design projectile with diameter smaller than diameter of the barrel. This sub-calibre projectile was lead within a barrel by guiding elements, which detached after the projectile left the cannon. To ensure, that a "thinner" projectile could carry the same amount of the explosives as a regular caliber projectile, the sub-calibre projectile has to be extended in length. The sub-calibre projectiles were 1.7-3.6 m long arrow shaped projectiles.

Sub-calibre projectiles made by Röchling were tested on Czech pre-WWII military bunkers (earlier occupied by Nazi-Wehrmacht) in October 1939 and in winter of 1940 in the Králíky area and three years later in Náchod area. Total sum of all sub-calibre projectiles fired on the Czech fortification were 139. Shots were fired from imminent distance $(66.3-200 \mathrm{~m})$, i.e. from unrealistic positions in the means of battlefield situation. These tests showed better efficiency of sub-calibre projectiles in comparison to regular ones.

The presented impact and penetration data comes from military archives and [1].

Shots fired from $21 \mathrm{~cm}$ howitzer with the same angle of impact lead to different penetration depths for regular and sub-calibre projectiles. For example subcalibre projectile Röchling $129 \mathrm{~mm}$ (weight $158 \mathrm{~kg}$ ) impact velocity $373.9 \mathrm{~m} / \mathrm{s}$ penetrated the reinforced concrete of the bunker $200 \mathrm{~cm}$ deep. On the other hand regular projectile of calibre $210 \mathrm{~mm}$ (weight $121.4 \mathrm{~kg}$ ) penetrated the concrete $45 \mathrm{~cm}$ deep with impact velocity $227.8 \mathrm{~m} / \mathrm{s}$. This represents a nearly four times greater efficiency. A $15 \mathrm{~cm}$ howitzer calibre tests lead to similar results for regular and sub-calibre projectiles.

\footnotetext{
${ }^{a}$ Corresponding author: pavel.jiricek@fsv.cvut.cz
}

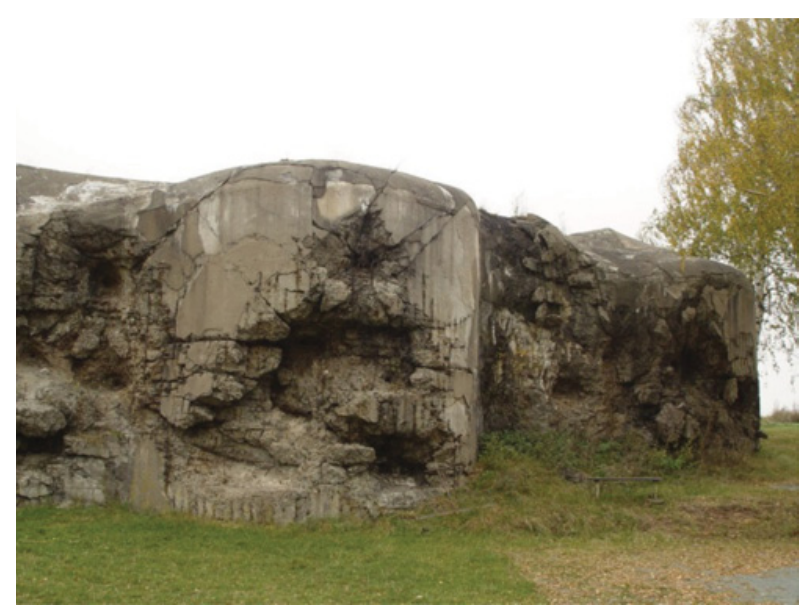

Figure 1. Front wall of the infantry bunker N-S-91 damaged by sub-calibre projectiles Röchling (the protective embankment was removed before the probe shootings).

The test results obtained from $21 \mathrm{~cm}$ calibre howitzer were used for numerical simulations. Both groups of the results are summed in Table 1 [1]. The projectiles were tested without the explosive content.

\section{Numerical simulations}

The evaluation of the effect of different calibre types projectiles requires complex computational models using nonlinear material models capable of handling high velocity impact behaviour. Due to these conditions ANSYS Autodyn was chosen.

\subsection{Computational model}

Computational model composes of bunker front wall section, dimensions $2 \times 2 \times 3.5 \mathrm{~m}$. Using Lagrangean

This is an Open Access article distributed under the terms of the Creative Commons Attribution License 4.0, which permits unrestricted use, distribution, and reproduction in any medium, provided the original work is properly cited. 
Table 1. Depth of penetration of regular and sub-calibre projectiles shot on bunker K-Bg-S-11 [1]. The analysed data sets are emphasized.

\begin{tabular}{|c|c|c|c|}
\hline $\begin{array}{l}\text { Type of the } \\
\text { projectile }\end{array}$ & $\begin{array}{c}\text { Impact } \\
\text { angle }\end{array}$ & $\begin{array}{l}\text { Impact } \\
\text { velocity }\end{array}$ & $\begin{array}{c}\text { Depth of } \\
\text { penetration }\end{array}$ \\
\hline \multirow{3}{*}{$\begin{array}{l}\text { Röchling } 15 \mathrm{~cm} \mathrm{Rö,} \\
\text { Gr., calibre } 105 \mathrm{~mm} \text {, } \\
\text { weight } 75 \mathrm{~kg}\end{array}$} & $70^{\circ}$ & $507.0 \mathrm{~m} / \mathrm{s}$ & $216 \mathrm{~cm}$ \\
\hline & $71^{\circ}$ & $460.9 \mathrm{~m} / \mathrm{s}$ & $199 \mathrm{~cm}$ \\
\hline & $85^{\circ}$ & $297.5 \mathrm{~m} / \mathrm{s}$ & $122 \mathrm{~cm}$ \\
\hline \multirow{3}{*}{$\begin{array}{l}\text { Anti-fortification } \\
\text { grenade } 15 \mathrm{~cm} \\
\text { Gr. } 19 \mathrm{Be} ., \\
\text { calibre } 150 \mathrm{~mm} \text {, } \\
\text { weight } 75 \mathrm{~kg}\end{array}$} & $71^{\circ}$ & $736.0 \mathrm{~m} / \mathrm{s}$ & $114 \mathrm{~cm}$ \\
\hline & $84^{\circ}$ & $520.5 \mathrm{~m} / \mathrm{s}$ & $67 \mathrm{~cm}$ \\
\hline & $76^{\circ}$ & $320.6 \mathrm{~m} / \mathrm{s}$ & $40 \mathrm{~cm}$ \\
\hline \multirow{3}{*}{$\begin{array}{l}\text { Röchling } 21 \mathrm{~cm} \mathrm{Rö,} \\
\text { Gr. } 44 \text { Be., } \\
\text { calibre } 129 \mathrm{~mm} \text {, } \\
\text { weight } 158 \mathrm{~kg}\end{array}$} & $85^{\circ}$ & $399.5 \mathrm{~m} / \mathrm{s}$ & $200 \mathrm{~cm}$ \\
\hline & $86^{\circ}$ & $373.9 \mathrm{~m} / \mathrm{s}$ & $200 \mathrm{~cm}$ \\
\hline & $88^{\circ}$ & $294.1 \mathrm{~m} / \mathrm{s}$ & $160 \mathrm{~cm}$ \\
\hline \multirow{3}{*}{$\begin{array}{l}\text { Anti-fortification } \\
\text { grenade } 21 \mathrm{~cm} \\
\text { Gr. } 18 \mathrm{Be} ., \\
\text { calibre } 210 \mathrm{~mm} \text {, } \\
\text { weight } 121,4 \mathrm{~kg}\end{array}$} & $75^{\circ}$ & $257.7 \mathrm{~m} / \mathrm{s}$ & $42 \mathrm{~m}$ \\
\hline & $87^{\circ}$ & $227.8 \mathrm{~m} / \mathrm{s}$ & $45 \mathrm{~cm}$ \\
\hline & $89^{\circ}$ & $289.9 \mathrm{~m} / \mathrm{s}$ & $77 \mathrm{~cm}$ \\
\hline
\end{tabular}

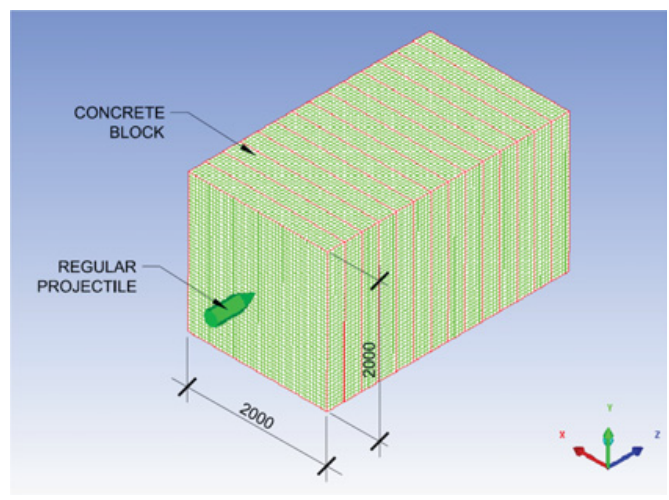

Figure 2. Computational model: regular projectile.

mesh with size of the elements $50 \times 50 \times 50 \mathrm{~mm}$, the part of the wall is divided into the layers with thickness $0.25 \mathrm{~m}$ to simplify the evaluation of the results. On the sides, top and the bottom of the wall displacement of the nodes are restricted. The boundary conditions are restraints corresponding to the dimensions of the surrounding structure. The dimension of the model was optimized to provide the best possible results with minimized computational time.

Material model of the military object's concrete wall is chosen to describe the damage of the wall during the impact. It is essential to take into account strain-rate effect of the concrete in case of high velocity impact loading.

Accordingly, the RHT concrete model was chosen. RHT Concrete is part of ANSYS Autodyn material library. Material model was set to match concrete grade C30/37; mean compressive strength of the concrete was $45 \mathrm{MPa}$ (the compressive strength of the concrete of the bunker as found in the military archives).

Geometry of both considered projectiles were modelled as accurate as possible. The material model of regular projectile was considered bilinear steel. Bilinear material model is chosen for sub-calibre projectile as well, but

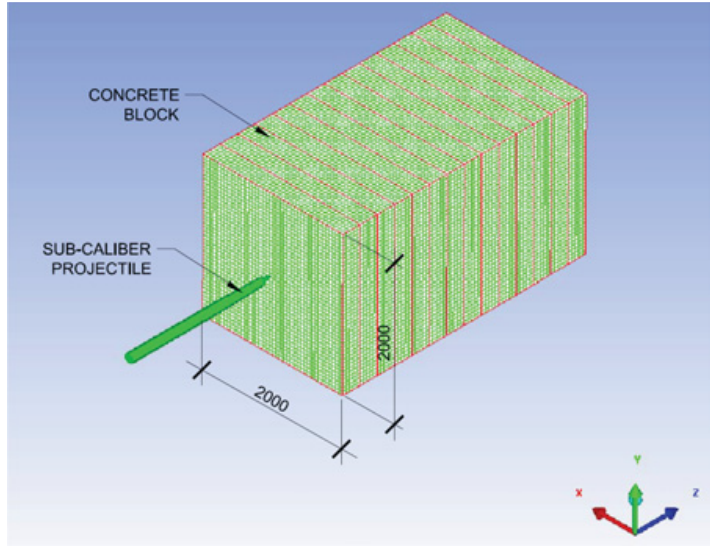

Figure 3. Computational model: sub-calibre projectile.

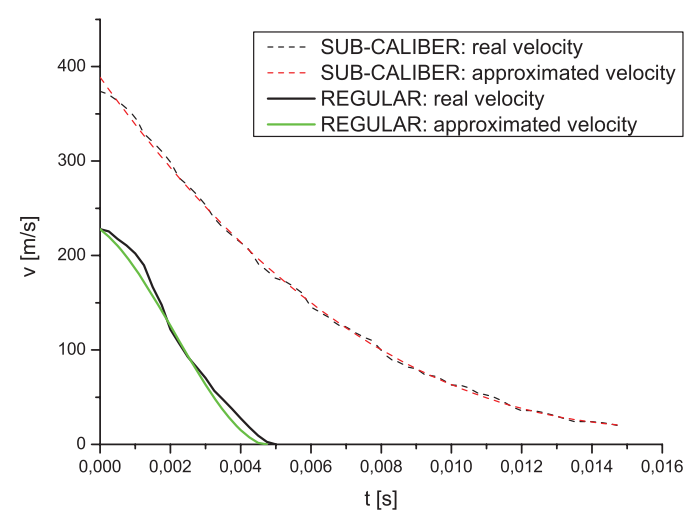

Figure 4. Graph plotting the peed of the projectile during the penetration of the concrete block.

steel is according to archive documents considered as chrome-vanadium with corresponding material properties, including the tip of the shot. Initial conditions are taken as presented in Table 1; velocity of sub-calibre projectile is set to $373.9 \mathrm{~m} / \mathrm{s}$ and $227.8 \mathrm{~m} / \mathrm{s}$ for regular calibre projectile.

The computational model was simplified in the mean of the impact angle, which was set to $90^{\circ}$. Guiding elements for sub-calibre projectile were neglected as well as the fletching, which has no effect on the impact itself and increase the computational time.

\subsection{Results}

\subsubsection{Regular projectile}

The numerical simulations resulted into a graph plotting the speed of the projectile during the penetration of the concrete block, see Fig. 4. Impact duration of the regular projectile is about $5 \mathrm{~ms}$ and the speed of the projectile can be approximated with a $3^{\text {rd }}$ degree curve.

The damage of concrete during penetration is an important parameter of impact modelling. Maximal damage on the front of the wall occurs during first $2.5 \mathrm{~ms}$ of the impact (Fig. 5).

The volume of crushed concrete is, in the case of regular projectile, cone shaped with depth $0.6 \mathrm{~m}$. The projectile itself penetrated wall $50 \mathrm{~cm}$ deep and crushed concrete volume is $0.14 \mathrm{~m}^{3}$ (Fig. 6). The results show 


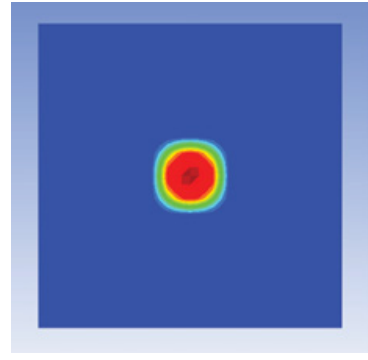

a) $0.5 \mathrm{~ms}$

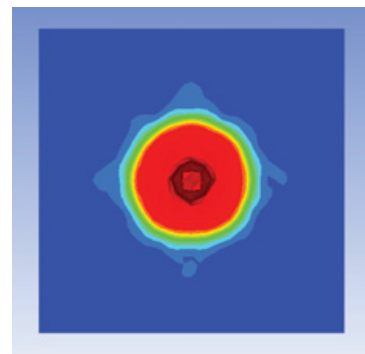

c) $2.5 \mathrm{~ms}$

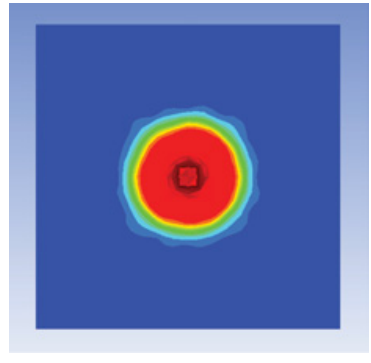

b) $1.5 \mathrm{~ms}$

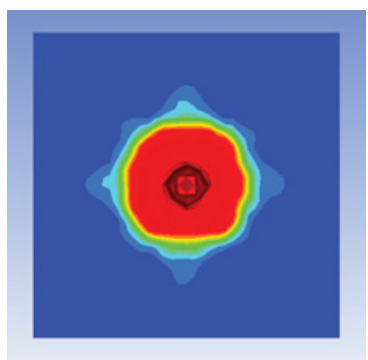

d) $4.5 \mathrm{~ms}$
Figure 5. Damage of the front of the wall in mean of time.

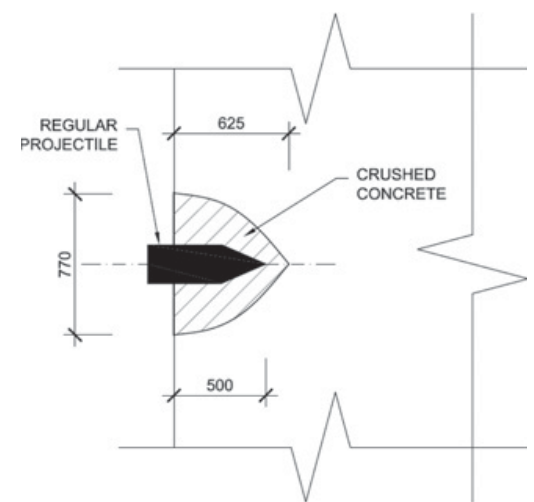

Figure 6. Shape of the resulting shape of damaged concrete: regular projectile.

great agreement with the documented penetrations (90\%) (Table 1).

\subsubsection{Sub-calibre projectile}

Unlike for the regular projectile, impact duration of subcalibre projectile is 3 times longer, $15 \mathrm{~ms}$. The curve of the velocity of the projectile during impact is quite different (Fig. 4) in comparison to the regular projectile but it can also be approximated with $3^{\text {rd }}$ degree curve.

According to the shape and speed of the sub-calibre projectile, maximal extent of damage of the concrete wall is approximately in the depth of $0.75 \mathrm{~m}$ and total damage permeates to the depth $2.2 \mathrm{~m}$. The volume of crushed concrete is $2.07 \mathrm{~m}^{3}$ and projectile itself is stuck $2.0 \mathrm{~m}$ deep in the wall. The agreement with documented penetrations is very good (over $90 \%$, Table 1).

\section{Comparison}

From the graph plotting the speed of the projectile during the penetration of the concrete block, a higher deceleration

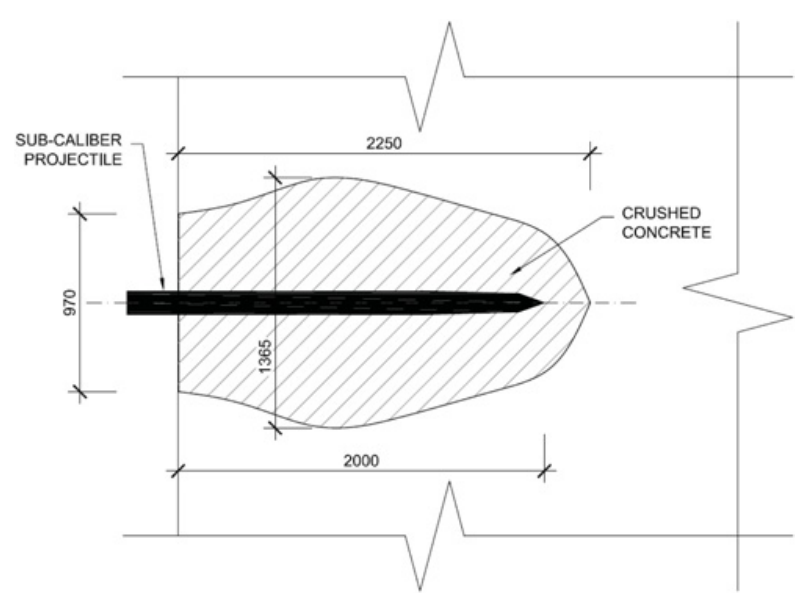

Figure 7. Shape of the resulting shape of damaged concrete: subcalibre projectile.

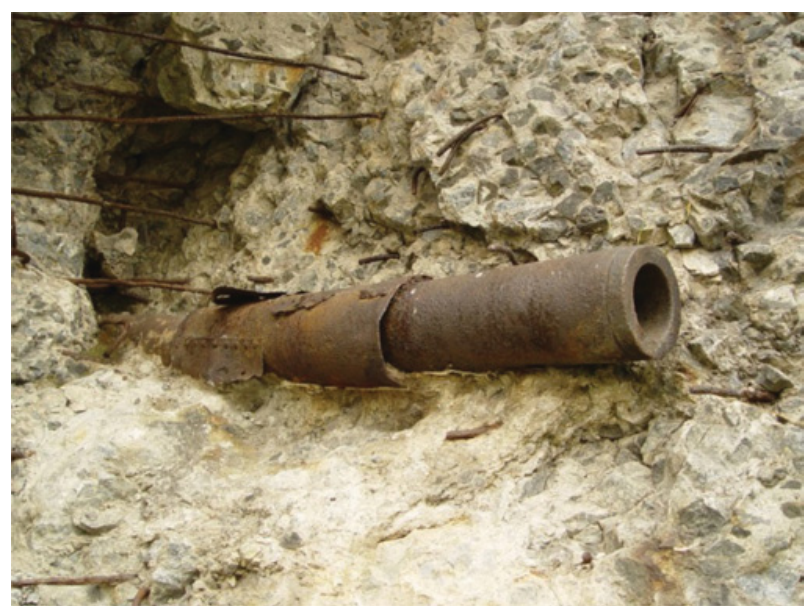

Figure 8. Sub-calibre projectile Röchling stuck in infantry bunker N-S-91.

of regular projectile compared to sub-calibre projectile can be seen. It is mostly caused by the shape of the projectiles. Regular projectile is approximately barrel shaped with cone in the front; the ratio of diameter to length is $1: 3$. On the other hand sub-calibre projectile is barrel shaped tapered from the middle of the length with cone in the front; the ratio of diameter to length is $1: 18$.

According to the shape and larger cross-sectional area, than sub-calibre projectile, the impact force of a regular calibre dissipates on the surface of the wall and the penetration is therefore shallow (Fig. 6). On the other hand sub-calibre projectile acts as a needle and the penetration is much deeper (Figs. 7 and 10). Similar results were obtained by numerical simulation of projectile with and without spike impacting concrete target with different volumes of fiber reinforcement [13].

As seen in Figs. (2 and 3), the shape and velocity of sub-calibre and regular projectiles during impact differ significantly. In the case of a regular projectile, the maximal damage of the concrete is on the front wall of the infantry bunker and subsequent slowdown of the projectile processes in short time lapse. Due to these circumstances, the whole kinetic energy is dissipated on the front of the wall. On the other hand, sub-calibre projectile penetrates 


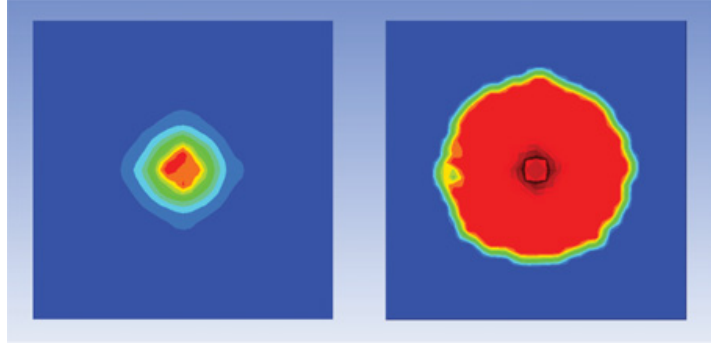

Figure 9. Damage of the front wall $0.5 \mathrm{~m}$ deep of the infantry bunker; left: regular projectile; right: sub-calibre projectile.

the concrete of the bunker much easier due to smaller diameter and higher speed, which can be seen at Figs. 4 and 7 . Thus, sub-calibre projectile causes more damage acts deeper than regular projectile.

The maximum damage is concentrated the surface of the wall, in the case of regular projectile and in the depth of $0.75 \mathrm{~m}$ in case of sub-calibre projectile. Marginal difference can be observed in volume of the crushed concrete, where regular projectile damages $0.14 \mathrm{~m}^{3}$ volume of the concrete and sub-calibre projectile $2.07 \mathrm{~m}^{3}$. Simultaneously sub-calibre projectile penetrates concrete wall $2.0 \mathrm{~m}$ deep in contrast to $0.5 \mathrm{~m}$ deep penetration of regular projectile.

Sub-calibre projectile weights $158 \mathrm{~kg}$ and its initial velocity is $373.9 \mathrm{~m} / \mathrm{s}$, that is $65 \%$ higher than regular projectile with speed $227.8 \mathrm{~m} / \mathrm{s}$ and weight $121.4 \mathrm{~kg}$. Kinetic energy can be basically expressed as:

$$
E_{k}=1 / 2 m v^{2} .
$$

The kinetic energy is $11 \mathrm{MJ}$ for sub-calibre projectile and $3 \mathrm{MJ}$ in case of regular projectile. Nearly 4 times lower energy of regular projectile than sub-calibre one matches lower volume of crushed concrete and damage on the front of the wall which should be larger than in case of subcalibre projectile.

Sub-calibre projectile penetrate concrete of the bunker much easily than regular projectile. Kinetic energy of the regular projectile is much lower than sub-calibre projectile, but decelerates three times shorter. Deceleration could be simply expressed as:

$$
a=\Delta v / \Delta t
$$

Using elementary physics (2) and simplified results, deceleration could be approximated to $45,000 \mathrm{~m} / \mathrm{s}^{2}$ for regular projectile and $25,000 \mathrm{~m} / \mathrm{s}^{2}$ in case of sub-calibre projectile. These simplified decelerations are used to evaluate impact force from the change of the momentum, 3.9 $\mathrm{MN}$ for sub-calibre projectile and 5.5 $\mathrm{MN}$ for regular projectile.

According to high velocities of impact loading on the front of the infantry bunker, significant strain-rate effect would occur. Dynamic increase factor (DIF), is well known phenomenon [2,3] based on increase of the concrete strength (both tensile and compressive) with higher impact loading and described as the ratio of dynamic strength to static strength. Strain-rates are approximately 90-/s for sub-calibre projectile and 200-/s in case of regular

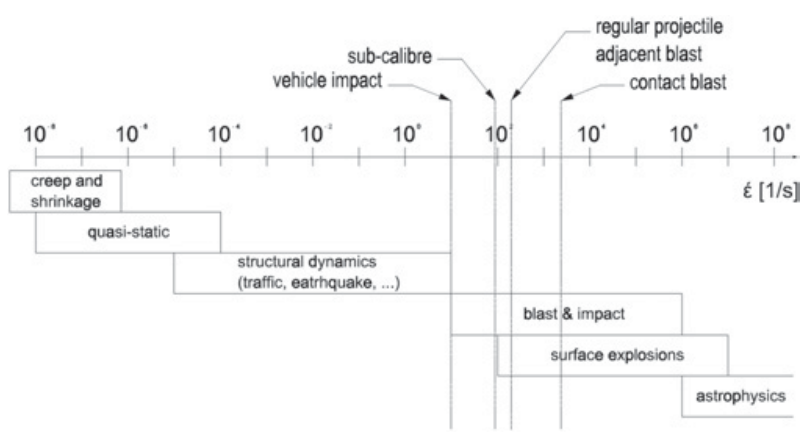

Figure 10. Strain rates of different dynamic loading cases, according to [3].

Table 2. Comparison of the results obtained from numerical simulation.

\begin{tabular}{|l|c|c|c|c|}
\hline $\begin{array}{l}\text { Type of the } \\
\text { projectile }\end{array}$ & $\begin{array}{c}\text { Weight } \\
\text { Weight }\end{array}$ & $\begin{array}{c}\text { Kinetic } \\
\text { energy }\end{array}$ & Deceleration & $\begin{array}{c}\text { Impact } \\
\text { force }\end{array}$ \\
\hline Regular & $121 \mathrm{~kg}$ & $3 \mathrm{MJ}$ & $45,000 \mathrm{~m} / \mathrm{s}^{2}$ & $5.5 \mathrm{MN}$ \\
\hline Sub-calibre & $158 \mathrm{~kg}$ & $11 \mathrm{MJ}$ & $25,000 \mathrm{~m} / \mathrm{s}^{2}$ & $3.9 \mathrm{MN}$ \\
\hline
\end{tabular}

Table 3. Comparison of the results of strain rates according to different types of extreme loading.

\begin{tabular}{|l|c|}
\hline Extreme loading & $\dot{\boldsymbol{\varepsilon}}[-/ \mathbf{s}]$ \\
\hline Vehicle impact [7] & 10 \\
\hline Sub-calibre & 90 \\
\hline Regular-calibre & 200 \\
\hline Adjacent blast [11,14] & 200 \\
\hline Contact blast [6] & 2,400 \\
\hline
\end{tabular}

projectile. According to [3], dynamic increase factor in the means of compressive strength reaches the value of 2.1 for sub-calibre projectile and 2.7 in case of regular projectile. The difference in strain-rate between sub-calibre and regular projectile is mainly the shape of the projectiles and the distribution of the energy during the impact loading and penetration.

Concrete as a semi-brittle material is very strain-rate sensitive. Strain rates obtained from several numerical simulation are plotted in Fig. 10, which presents values of strain rate for different dynamic loadings. For better understanding, findings from previous studies are presented. Vehicle impact loading [7] strain rates are approximately 10-/s which represents the top of the range of structural dynamics (Fig. 10). Adjacent blast [11], [14] strain rates come up to same values as regular projectile and corresponds with range for blast and impact range given by [3]. The highest strain rates are obtained during contact blast [6].

For the in Table 3 presented strain rates, the value of dynamic increase factor (DIF) can reach values from 1.15 to 37.25 according to the approach used; for details see [12].

The total effectiveness of the used ammunition is much considering the explosives fillings of the projectiles, because the sub-calibre projectile detonates as a recessed charge [4], which is more effective than contact explosion $[5,6]$ of charge of the regular projectile. 


\section{Conclusions}

The presented simulation was performed to evaluate penetration of two types of the projectiles to the front wall of a military bunker. The sub-calibre projectile penetrates the concrete 4 times deeper than regular projectile and is therefore more effective.

According to depth of penetration of the projectiles into wall of the bunker, substantial compliance with archive data and was achieved [1]. The shape and depth of damage caused by the projectiles in numerical simulations is similar to the one observed on tested bunkers. The obtained results show that the described numerical simulations can be used to predict similar situations.

The financial support of the Czech Science Foundation grant project 13-30441S is gratefully acknowledged.

\section{References}

[1] M. Ráboň, O. Gregar, B. Kachlík, et. al., Val na obranu republiky - Československé opevnění $z$ let 1935-1938 na Králicku (Spolek přátel československého opevnění Brno, s.r.o., Brno, 2005)

[2] M. Drahorád, et. al., Beton TKS, 1/2012, 74-79 (2012)
[3] CEB-FIP Model Code 2010, Comité EuroInternational du Béton, (2010)

[4] J. Henrych, Dynamika výbuchu a její užití (Academia, Praha, 1973)

[5] M. Foglar, et. al., Beton TKS, 4/2011, 90-93 (2011)

[6] M. Foglar, M. Kovář, International Journal of Impact Engineering, 59, 18-28, (2013)

[7] P. Jiříček, M. Foglar, Bridge Maintenance, Safety, manegement and Life Extension 2014, 762-768, (2014)

[8] CEB-FIP Model Code 1990, Comité EuroInternational du Béton, (1993)

[9] L. J. Malvar, C. A. Ross, ACI Material Journal, 95(6), 735-739, (1998)

[10] J. W. Tedesco, C. A. Ross, Journal of Pressure Vessel Technology, 120(4), 398-405, (1998)

[11] E. Sochorová, M. Foglar V. Křístek, Reliability, Risk and Safety. Back to the Future, 1-8 (2010)

[12] P. Jiříček, M. Foglar, Proceeding of 23rd Military Aspects of Blast and Shock 2014, (2014)

[13] U. Nyström, K. Gylloft, International Journal of Impact Engineering, 38, 95-105, (2011)

[14] M. Foglar, J. Pachman, V. Pelikán, R. Hájek, M. Künzel, WIT Transactions on The Built Enviroment, 141, 171-179, (2014)

[15] M. Kovár, M. Foglar, R. Hájek, WIT Transactions on The Built Enviroment, 141, 159-169, (2014) 